\title{
Trade in the telecoupling framework: evidence from the metals industry
}

\author{
$\underline{\text { Hang Xiong }}^{1,2}$, James D. A. Millington ${ }^{2}$ and $\underline{W e i}^{X_{u}}{ }^{3,4}$
}

\begin{abstract}
As a conceptual framework for understanding contemporary sustainability challenges, telecoupling emphasizes the importance of socioeconomic and environmental interactions over long distances. These long-distance interactions can occur through multiple human activities. We focus on international trade, a major channel of telecoupling flows, and in particular on the international trade of metals. We use the data of physical products and embedded greenhouse gas (GHG) emissions trade in the World Input-Output Database (WIOD) to quantitatively examine how countries contribute to both economic and environmental flows through the trade of metals, but also how that contribution varies depending on their position in the global value chain (GVC) of contemporary international trade. This analysis is built on previously developed techniques for decomposing gross exports of products, which we apply to examine embedded GHG emissions. We make comparisons between countries' contributions to flows of economic value versus embedded GHG emissions, but also examine contributions beyond total volumes of trade and bilateral trade. Specifically, we quantify the economic and environmental spillover effects that occur in contemporary international trade because of the GVC in which flows of intermediate goods form components in other subsequently traded goods. We interpret differences between countries' contributions to the flows of economic value versus embedded GHG emissions as being related to the intensity and efficiency of resource use during production. In turn, differences in contributions to direct trade flows versus spillover flows are related to their positions in the GVC. Subsequently, we discuss other elements of the telecoupling framework in trade, i.e., agents, causes, and effects. Quantitatively incorporating these telecoupling framework elements alongside spillover flows will enable investigation of dynamics and relationships that traditional trade theories, data, and models do not currently account for well.
\end{abstract}

Key Words: global value chain; international trade; metal industry; telecoupling framework; world input-output database

\section{INTRODUCTION}

The conceptual framework of telecoupling (Liu et al. 2013, 2015) highlights the importance of socioeconomic and environmental interactions over large distances for understanding contemporary sustainability challenges. The framework integrates five elements: coupled human and natural systems (CHANS), flows, agents, causes, and effects. Local interactions within CHANS are mediated by agents making decisions, with socioeconomic and environmental causes and effects. Furthermore, in the telecoupling framework, CHANS are the origin and destination of long-distance interactions, connected by material and information flows, and can be distinguished from those that are sending systems, those that are receiving systems, and those that are recipients of spillover flows from the interaction of other systems. As highlighted previously (e.g., Liu et al. 2013), longdistance telecoupling interactions can occur through multiple human activities such as international trade, foreign direct investments, transregional projects by governments, migration by refugees, and travel by tourism, and through natural processes like the hydrologic cycle, atmospheric circulation, seed dispersal, and annual animal migrations. We focus on international trade, a major channel of telecoupling flows but which also often couples human systems with natural systems.

Trade in general is a typical case of flows in telecoupling because both the production activities in an exporting country and the consumption activities in an importing country have socioeconomic and environmental effects. Through international trade, one country's demand can be another country's motivation to provide a product, thereby changing the use of natural resources or environmental assets (broadly defined as "the naturally occurring living and non-living components of the
Earth, together constituting the biophysical environment, which may provide benefits to humanity," according to the Central Framework 2012 of United Nations' System of EnvironmentalEconomic Accounting) in the other country (United Nations 2014:13). For example, Brazilian farmers have been shown to convert forests into land for farming soybeans to meet international demand for the product, mainly driven by China (Fearnside et al. 2013). In addition to land conversion issues, international trade also contributes to ecologically unequal exchange. Many studies reveal that developing nations export natural resource intensive commodities to developed nations, thereby allowing wealthy economies to avoid operating ecologically impactful industries at home (e.g., Davis and Caldeira 2010, Moran et al. 2013, Prell and Sun 2015).

Traditional studies of trade have focused on direct human benefits from goods and services. Neoclassical economic theories treat environmental problems as epiphenomena and tend to reserve judgement about them (Karp 2011). Not surprisingly, none of the mainstream trade theories (i.e., the classical trade theories developed in the 18th and 19th century to the "new" new trade theory developed in recent two decades) considers the environmental consequences of trade. From the telecoupling perspective these trade theories do not enable comprehensive consideration of CHANS. The environmental impacts of economic activities have become of increasing concern, and since the 1960s, the environmental aspects of trade have come to receive more attention (Cropper and Oates 1992, Frankel 2009). One of the first important systematic analyses of the relationship between trade and the environment was published in the early 1990s (Grossman and Krueger 1991), laying the basis for other widely studied theories such as the environmental Kuznets curve

\footnotetext{
${ }^{1}$ Agricultural Economics and Policy Group, ETH Zurich, ${ }^{2}$ Department of Geography, King's College London, ${ }^{3}$ School of Public Administration,
} Fujian Agriculture and Forestry University, ${ }^{4}$ School of Management, Zhejiang University 
Fig. 1. Trade in the telecoupling framework. Our emphasis is on flows, which we quantify for the global trade of metal products and their embedded environmental assets (green and red arrows).

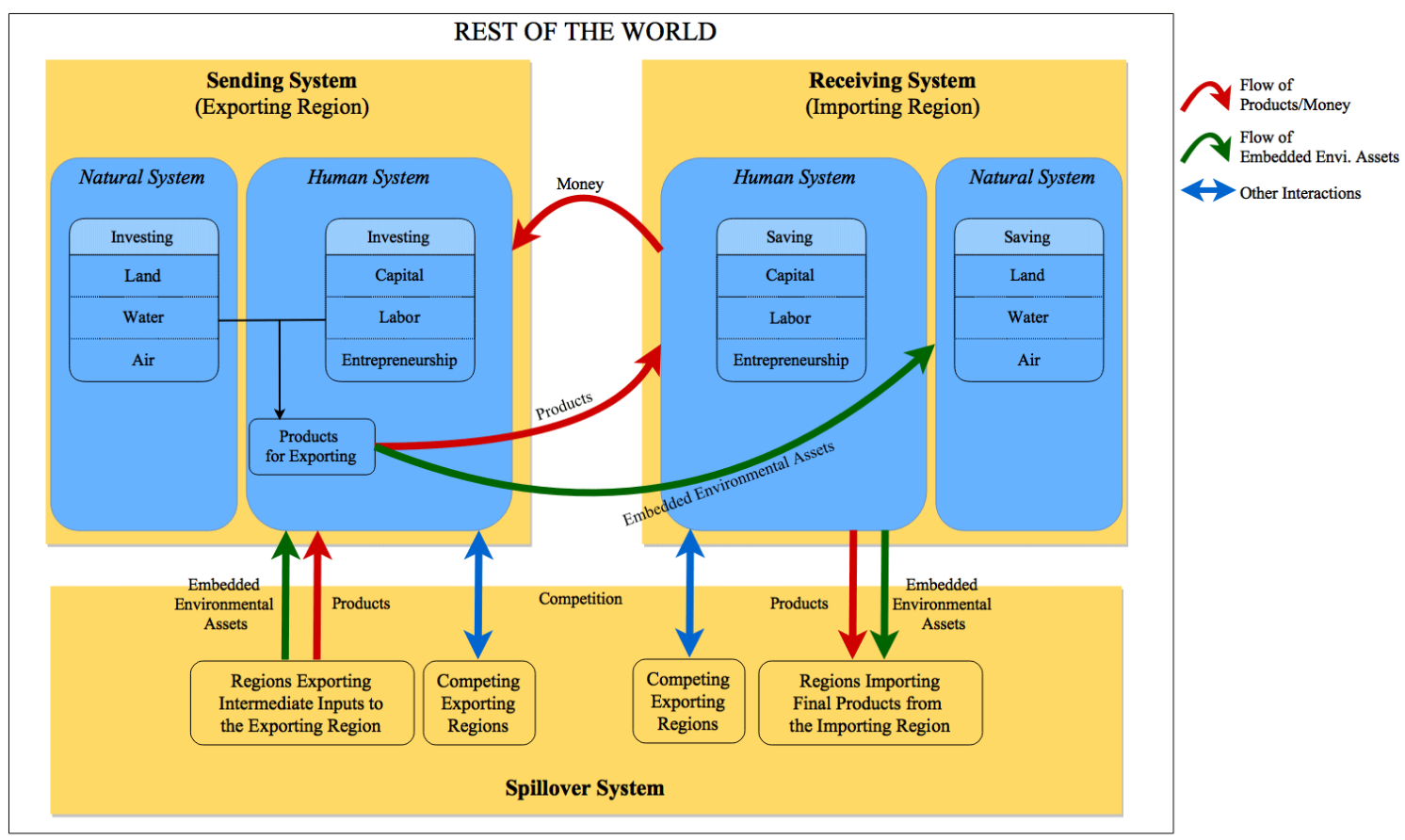

hypothesis (Grossman and Krueger 1991, Shafik and Bandyopadhyay 1992) and the pollution haven hypothesis (Tobey 1990, Mani and Wheeler 1998).

More recently, the unequal exchange of natural resources through trade has been examined using the input-output approach (Moran et al. 2013, Prell et al. 2014, Prell and Sun 2015, Prell and Feng 2016). This approach enables accounting of emissions associated with consumption, including both intermediate consumption and final consumption, as defined in global value chain (GVF) literature (see Timmer et al. 2015), of goods and services (Peters 2008, Peters and Hertwich 2008, Hertwich and Peters 2009). A substantial portion of global carbon emissions is traded internationally, primarily as exports from developing countries to consumers in developed countries (Davis and Caldeira 2010, Davis et al. 2011, Steinberger et al. 2012, Prell et al. 2017). We build on the input-output approach and incorporate it into the telecoupling framework, showing how it is useful for examining economic and environmental consequences of global trade.

Our primary aim is to contribute to improvements in the quantification and analysis of key concepts in the telecoupling framework, focusing in particular on flows between CHANS. We do this by examining the international trade of metals to show how recently developed data sources and accounting methods enable the examination of economic and environmental impacts, both of which must be considered in the telecoupling framework. Furthermore, in contemporary international trade, goods are often composed of component parts that have been previously imported from other countries. Consequently, the flow of embedded environmental assets around the world cannot be captured by considering bilateral trade between two countries alone and must include consideration of (multiple) third parties. In the telecoupling framework, these third-party flows are known as spillover flows, but to date have received limited attention. Spillover flows occur in contemporary international trade because of its dependence on a global value chain (GVC) in which flows of intermediate goods form components in other subsequently traded goods. Using contemporary data sources and accounting methods for trade in the global metals industry, we make one of the first quantitative analyses of spillover flows in a telecoupled system.

\section{TRADE VIEWED THROUGH THE TELECOUPLING FRAMEWORK}

Our conceptual model of international trade viewed through the telecoupling framework focuses on flows between CHANS (Fig. 1). The key flows in trade are those of products, money, and embedded environmental assets, the latter of which is most important when considering physical goods (as opposed to information products or services). When viewing international trade through the telecoupling framework, the sending system is the country exporting products and the receiving system is the country importing products. Products flow from the exporting country into the importing country through some form of transportation or communication. As a return, money flows in the opposite direction from the importing country to the exporting country. Through trade, an importing country substitutes these resources that they would otherwise need to consume from their own resources (Norder et al. 2017). Thus, along with the flow of physical products and money, the environmental assets consumed in production travel from the exporting country to the importing country and can be thought of as being substituted from the importing country's resources. 
Fig. 2. Spillover effects in international telecoupled trade. Trade between countries to the right of the figure induce production and consumption of resources in countries to the left of the figure. Dotted arrows indicate exports of intermediate products, and whole solid arrows indicate exports of final products. Letters and numbers are referred to in the Methods section.

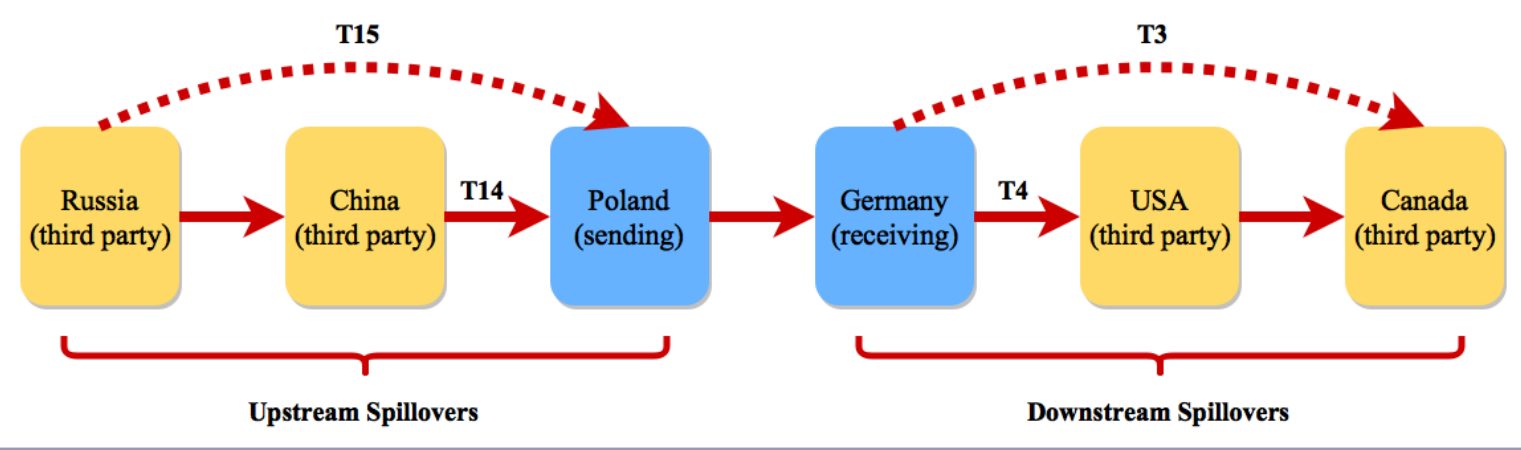

The representation and consideration of spillovers within the telecoupling framework enables explicit consideration of relationships of flows of embedded environmental assets between systems. In particular, spillover systems in international trade are the countries affected by the interaction between exporting and importing countries, often the production or consumption of the traded products through a third country. For example, the production of automobiles in Germany for export to USA uses component parts imported from Poland, which were produced using steel provided by China (Diehl 2001, Meng et al. 2015). The trade between Germany and USA, therefore, induces the production (and consumption) of environmental assets in the third party countries of Poland and China (Fig 2.).

Thus, in contemporary telecoupled international trade, coupled human-natural systems (i.e., countries in this study) often produce goods for export using imported intermediate products from other systems, which further use intermediate inputs from an upstream sector through imports from other systems (and so on upstream for previous imports). We refer to such interactions between flows as upstream spillover effects because they are caused by the production in the sending system (e.g., exporting country) spilling over to the upstream sectors in the spillover system (e.g., third party countries). Alternatively, spillover effects can also occur through consumption of the downstream sectors in the spillover system. In the automobile example above, the consumption of automobiles in the USA contributes to Germany's import of component parts from Poland, who further import steel from China (see Fig. 2). From this perspective, we see the interactions between flows as downstream spillover effects.

In addition, these spillovers may vary through time because of competition for imports or exports with other supply or demand countries. Because these interactions are usually implicit or subtle and thus are difficult to measure, we focus on upstream and downstream spillover flows. Using a case study of the international trade in the metals industry, we define these spillover effects further below and show how they can be quantified for better understanding of flows in telecoupled systems.

\section{DATA AND METHODS}

\section{Data}

This study uses multiregional input-output (MRIO) tables to quantify the net flows and spillover flows of products and embedded greenhouse gas (GHG) emissions (i.e., the emissions attributed to the production of the products being consumed; see Li et al. 2007, Weber and Matthews 2007, Peters et al. 2011). The MRIO approach considers a full range of inputs located across different countries in bringing a product from its conception to the final consumer (Gibbon et al. 2008, Baldwin and LopezGonzalez 2015). It thus provides a sector-by-sector track of the value and environmental assets added by each country in the production chain of goods that are consumed worldwide. Specifically, we use the World Input-Output Database (WIOD, http://www.wiod.org), a database containing trade flows for 35 sectors of an economy in 41 global regions (40 major countries with the remainder wrapped up as "Rest of the World"). There are other MRIO databases to consider, but they each have some disadvantages compared to WIOD: EORA (http://www. worldmrio.com) has a lower sector-resolution, with only a 26sector harmonized classification; EXIOBASE (http://www. exiobase.eu) is less timely, with the latest update at 2007; and OECD-ICIO database misses many emissions sources for its $\mathrm{CO}_{2}$ emission factors (Wiebe and Yamano 2016). A limitation of the WIOD is that it does not include as many countries as other databases. However, because the major trading countries in the world are included (mainly developing world countries are missing), this limitation does not substantially affect our analyses.

Socioeconomic accounts of the WIOD provide data on value added (i.e., net flow of products and money), whereas the environmental accounts refer to atmospheric emissions (for all greenhouse gases, plus selected others) and water use. The data for both socioeconomic and environmental accounts are currently available up to the year 2009. We use the 2009 data to quantify the flows and spillovers in the world trade of the sector "basic metals and fabricated metal products, except machinery and equipment" (code $27 \mathrm{t} 28$ in WIOD, hereafter "metals"). The metals sector is chosen because it is a typical sector with high 
emissions and with a large proportion of the emissions traded internationally. Specifically, the production in this sector generates $7 \%$ of the world's $\mathrm{CO}_{2}$ emissions (second greatest among all 35 sectors worldwide) and over $40 \%$ of the production is exported, which leads to $11 \%$ of the world's trade of embedded $\mathrm{CO}_{2}$ emissions (also second largest; according to WIOD). We present how to quantify the flows and spillovers in the telecoupling framework by focusing on a single year. Dynamic analysis can be conducted by applying our method to other years.

\section{Methods}

We use the method proposed by Johnson and Noguera (2012) to quantify the flows of value added and embedded environmental assets between sending and receiving systems, and the method proposed by Wang et al. (2013) to quantify these flows between sending systems and spillover systems (i.e., spillover flows). Johnson and Noguera (2012) provided the measure of value added exports (VAX), the value added produced in the source country and absorbed in the destination country. The measure thus represents the net flow of value added from exporting to importing countries. By applying this measure to gas emissions data, technologically, replacing the value added coefficient vector by direct emission intensity vector in the decomposition formulas as for example, Meng et al. (2015) does previously, we also computed the flows of embedded GHG emissions.

The quantification of spillover flows is more challenging because it requires a more detailed decomposition of gross exports so that value added or embedded environmental assets sourced from nondirect trading partners (i.e., third parties) can be identified. Wang et al. (2013) provided a procedure decomposing bilateral sector-level gross trade flows into various value added and doublecounted components. Refer to Appendix 1 for a graphic display of the decomposition results (Appendix 1, A1.1) and a detailed explanation of which components constitute the upstream and downstream spillovers.

Performing the Wang et al. (2013) method directly produces the upstream and downstream spillover flows of value added. We then applied it to the emissions data, as we did with the Johnson and Noguera (2012) method, to calculate the upstream and downstream spillover flows of embedded GHG emissions. A summary of the steps analyzing the WIOD data is presented in Appendix 2.

In addition, some indication of countries' relative position in the GVC is necessary to understand differences in their potential to induce spillovers. This can be given by upstreamness, a measure of the distance to final demand in terms of the production stages a particular product goes through (Antràs and Chor 2013). A country that produces intermediate inputs within the GVC has a greater upstreamness than a country producing a final product, and the more production stages that the intermediate inputs need to go through to reach final consumers, the greater the upstreamness. In the above example (Fig. 2), China has greater upstreamness than the USA (3.66 versus 3.13). We calculate each country's value of upstreamness using the method that Antràs et al. (2012) presented. Finally, to understand countries' contributions to GHG emissions, a measure of emissions intensity is required. We calculated this $\mathrm{GHG}$ emissions intensity per region as the volume of emissions in production per unit gross output, as has been done previously (e.g., Meng et al. 2015).

\section{RESULTS}

\section{Flow of products}

For the 40 countries (plus combined Rest of the World; RoW) analyzed, we found that 19 countries have positive net VAX, and 21 (including RoW) are net importers (Table 1). The results show that the sources of VAX are concentrated in a handful of countries and the primary import destination is the USA. The largest five net exporters (Japan, Germany, China, Italy, and South Korea), for instance, are the source of over $80 \%$ of net export flows. Conversely, the USA receives nearly a quarter of metals from the world market, five times the second largest receiver, India.

By decomposing each country's gross export to its sources (the exporting country, the importing country, and third parties) and the form it is exported (final products and intermediate inputs), we are able to plot the flows of value added between the 41 countries (Fig. 3). Japan, the largest net exporter, provides metal goods (in either final or intermediate state) primarily to the USA, China, South Korea, and to European countries. South Korea has similar customers to Japan. Another major Asian net exporter, China, sends the majority of its products to the USA and receives products from Japan and South Korea. Our decomposition also shows that intra-EU trade is active because most EU members both receive value added from and send value added to other EU members. Two major European net exporters, Germany and Italy, also have a substantial outflow to the USA.

Fig. 3. Flows of value added exports (VAX) in metal products trade worldwide. Country codes are specified in Table 1.

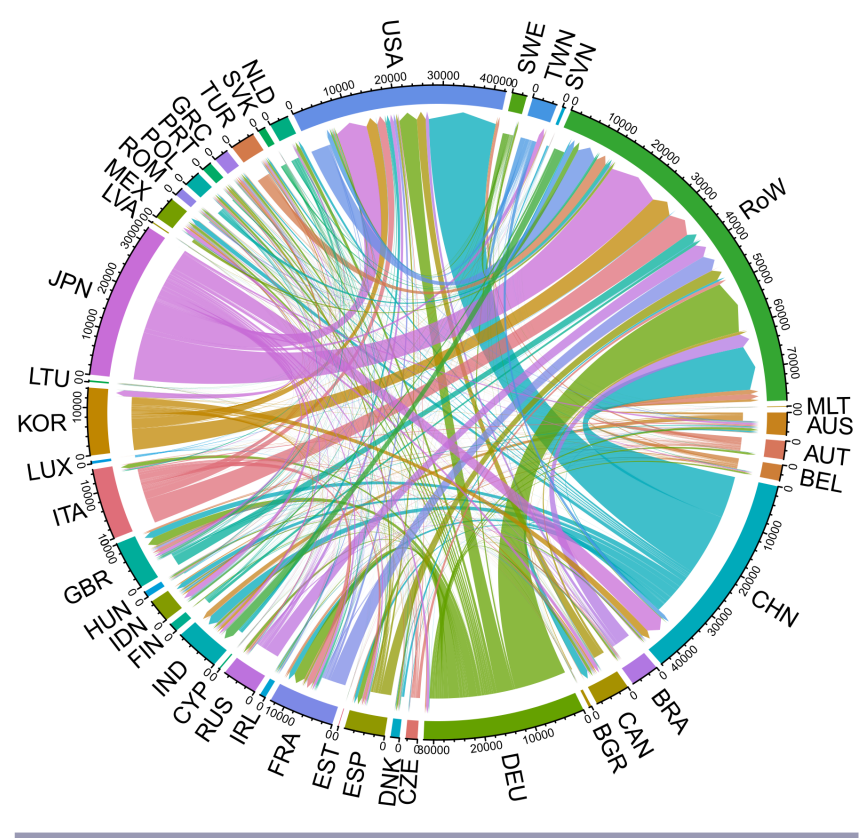

Flow of embedded greenhouse gas (GHG) emissions

Analysis of flows of GHG emissions embedded in metals trade (for 38 countries and RoW, but excluding Romania and Luxembourg for which the data are unavailable), shows that $48 \%$ of total emissions are embedded in products exported by China, followed by Russia (28.9\%), and South Korea (9.5\%; Table 1). 
Table 1. Net flows of value added export (net VAX), gross export (Export), upstreamness (from Antràs et al. 2012), net flows of embedded greenhouse gas (GHG) emissions (net GHG), and GHG emissions intensity (GHG intensity) by country. For net VAX and net GHG, positive values indicate net export and negative values indicate net import. For ranks, 1 is the greatest value. All $\$$ values are US\$.

\begin{tabular}{|c|c|c|c|c|c|c|c|c|c|c|c|}
\hline Country & Code & $\begin{array}{l}\text { Net VAX } \\
\text { (bil. \$) }\end{array}$ & $\begin{array}{l}\text { Net VAX } \\
\text { rank }\end{array}$ & $\begin{array}{l}\text { Export } \\
\text { (bil. \$) }\end{array}$ & Export rank & $\begin{array}{l}\text { Upstream- } \\
\text { ness }\end{array}$ & $\begin{array}{l}\text { Upstream- } \\
\text { nessrank }\end{array}$ & $\begin{array}{l}\text { Net GHG } \\
\quad(\mathrm{Mt})\end{array}$ & $\begin{array}{l}\text { Net GHG } \\
\text { rank }\end{array}$ & $\begin{array}{c}\text { GHG } \\
\text { intensity } \\
(\mathrm{t} / \$)\end{array}$ & $\begin{array}{c}\text { GHG } \\
\text { intensity } \\
\text { rank }\end{array}$ \\
\hline China & $\mathrm{CHN}$ & 28.44 & 3 & 75.24 & 4 & 3.66 & 2 & 126.19 & 1 & 2.44 & 5 \\
\hline Russia & RUS & 3.99 & 6 & 23.97 & 13 & 3.55 & 4 & 75.94 & 2 & 7.21 & 2 \\
\hline \multicolumn{11}{|l|}{ Korea } & 8 \\
\hline Taiwan & TWN & 2.39 & 9 & 21.51 & 15 & 3.59 & 3 & 9.26 & 4 & 2.27 & 6 \\
\hline Japan & JPN & 32.91 & 1 & 77.33 & 3 & 3.42 & 5 & 7.16 & 5 & 0.81 & 24 \\
\hline India & IND & -6.80 & 39 & 14.92 & 21 & 2.68 & 38 & 5.54 & 6 & 3.74 & 4 \\
\hline Czech Rep. & $\mathrm{CZE}$ & 1.79 & 11 & 10.12 & 24 & 3.25 & 9 & 4.92 & 7 & 1.82 & 9 \\
\hline Slovakia & SVK & 1.15 & 16 & 6.57 & 25 & 3.07 & 19 & 3.73 & 8 & 2.23 & 7 \\
\hline Austria & AUT & 2.72 & 8 & 18.60 & 18 & 3.01 & 21 & 1.56 & 9 & 0.96 & 20 \\
\hline Poland & POL & 0.04 & 19 & 13.48 & 22 & 2.95 & 30 & 1.54 & 10 & 1.44 & 13 \\
\hline Indonesia & IDN & -4.75 & 38 & 6.38 & 27 & 3.10 & 18 & 1.45 & 11 & 5.77 & 3 \\
\hline Finland & FIN & 1.31 & 14 & 6.53 & 26 & 3.40 & 6 & 0.31 & 12 & 0.96 & 19 \\
\hline Australia & AUS & -0.82 & 28 & 2647 & 11 & 3.14 & 14 & 0.06 & 13 & 1.55 & 11 \\
\hline Malta & MLT & -0.14 & 24 & 0.03 & 41 & 1.91 & 41 & 0.02 & 14 & 11.68 & 1 \\
\hline Latvia & LVA & -0.12 & 23 & 0.64 & 37 & 3.18 & 13 & -0.17 & 15 & 1.47 & 12 \\
\hline Estonia & EST & -0.02 & 20 & 0.61 & 38 & 2.87 & 34 & -0.25 & 16 & 0.29 & 36 \\
\hline Bulgaria & BGR & -0.05 & 21 & 2.96 & 33 & 3.24 & 10 & -0.28 & 17 & 1.14 & 16 \\
\hline Brazil & BRA & 3.38 & 7 & 15.22 & 20 & 2.98 & 26 & -0.31 & 18 & 0.97 & 18 \\
\hline Cyprus & CYP & -0.28 & 25 & 0.23 & 40 & 2.82 & 36 & -0.33 & 19 & 0.52 & 29 \\
\hline Hungary & HUN & -0.89 & 29 & 3.51 & 30 & 2.98 & 27 & -0.47 & 20 & 1.58 & 10 \\
\hline Slovenia & SVN & 0.43 & 18 & 2.82 & 34 & 2.99 & 24 & -0.55 & 21 & 0.29 & 35 \\
\hline Lithuania & LTU & -0.33 & 26 & 0.39 & 39 & 2.51 & 40 & -0.67 & 22 & 0.08 & 39 \\
\hline Ireland & IRL & -1.15 & 31 & 1.03 & 36 & 3.01 & 22 & -1.05 & 23 & 1.21 & 15 \\
\hline Turkey & TUR & 1.18 & 15 & 19.41 & 17 & 2.97 & 29 & -1.37 & 24 & 1.09 & 17 \\
\hline Sweden & SWE & 1.82 & 10 & 12.33 & 23 & 3.20 & 12 & -1.70 & 25 & 0.50 & 30 \\
\hline Belgium & BEL & 1.72 & 12 & 28.36 & 10 & 3.21 & 11 & -1.77 & 26 & 0.67 & 25 \\
\hline Portugal & PRT & -1.60 & 32 & 3.47 & 31 & 3.01 & 23 & -2.44 & 27 & 0.10 & 38 \\
\hline Denmark & DNK & -0.48 & 27 & 4.65 & 28 & 2.90 & 32 & -2.97 & 28 & 0.11 & 37 \\
\hline Greece & GRC & -2.88 & 35 & 2.46 & 35 & 2.61 & 39 & -4.34 & 29 & 0.36 & 33 \\
\hline Netherlands & NLD & -0.11 & 22 & 21.23 & 16 & 3.07 & 20 & -4.80 & 30 & 0.61 & 27 \\
\hline Mexico & MEX & -3.21 & 36 & 15.94 & 19 & 2.77 & 37 & -5.09 & 31 & 0.87 & 23 \\
\hline Canada & CAN & -1.74 & 33 & 30.39 & 9 & 2.97 & 28 & -5.33 & 32 & 0.91 & 21 \\
\hline Spain & ESP & 1.40 & 13 & 22.30 & 14 & 3.26 & 8 & -7.37 & 33 & 0.40 & 32 \\
\hline Germany & DEU & 30.04 & 2 & 113.88 & 2 & 3.13 & 16 & -8.68 & 34 & 0.59 & 28 \\
\hline UK & GBR & -3.96 & 37 & 24.88 & 12 & 2.86 & 35 & -8.77 & 35 & 0.88 & 22 \\
\hline Italy & ITA & 11.79 & 4 & 48.22 & 6 & 2.88 & 33 & -12.80 & 36 & 0.30 & 34 \\
\hline France & FRA & -2.02 & 34 & 33.53 & 8 & 3.10 & 17 & -15.34 & 37 & 0.44 & 31 \\
\hline United & USA & -33.16 & 40 & 59.42 & 5 & 3.13 & 15 & -87.14 & 38 & 0.64 & 26 \\
\hline States & & & & & & & & & & & \\
\hline $\begin{array}{l}\text { Rest of } \\
\text { World }\end{array}$ & RoW & -72.62 & 41 & 137.84 & 1 & 2.92 & 31 & -88.81 & 39 & 1.36 & 14 \\
\hline Luxembourg & LUX & 0.54 & 17 & 3.05 & 32 & 3.30 & 7 & NA & NA & NA & NA \\
\hline Romania & ROU & -1.13 & 30 & 3.68 & 29 & 2.99 & 25 & NA & NA & NA & NA \\
\hline
\end{tabular}

East Asia countries (i.e., China, Japan, and South Korea) have a dominant role in exporting embedded GHG emissions around the world, accounting for two-thirds of the total. Most European countries, however, are net receivers. The major European net exporters of value added goods, such as Germany, Italy, and Sweden, are also large net receivers of embedded GHG emissions. The few net senders of embedded GHG emissions in Europe, such Czech Republic, Slovakia, and Austria export small volumes relative to the three major exporters. Not surprisingly, as the largest net importer of products, the USA is also the largest net receiver of GHG, with one-third of the world's embedded emissions flowing into it.

When flows of embedded GHG emissions are decomposed into specific sender and receiver systems (Fig. 4), we find that China provides about half of the embedded GHG emissions of USA imports and a substantial portion of the European imports. China is also a net exporter to Japan, which is the reverse of the situation for products (see Table 1). Another striking net exporter of embedded GHG emissions is Russia, related to its extremely high GHG emission intensity $(7.21 \mathrm{kCO} / \$$, the highest among large economies) and very high upstreamness $(\mathrm{U}=3.55$, the third highest among large economies, following South Korea and China). In contrast, the USA is a primary destination of flows from many countries around the world (importing 87.14 Mt from 29 countries).

\section{Spillover flows}

Germany generates the greatest upstream spillovers, valued at $\$ 17.30$ billion over all third parties (dark red bars in Fig. 5), which 
is understandable considering it is the largest gross exporter of metals (Table 1). China and South Korea, however, generate more upstream spillover than Japan, the second largest gross exporter. This indicates that China and South Korea's production of value added goods for export uses a large number of products produced elsewhere, and thus their metal industries are more reliant on imports from other countries than Japan. Similarly, the USA, the fourth largest exporter, generates less upstream spillover than the countries that export less (Belgium, Italy, and Canada) because it uses relatively fewer products imported from other countries.

Fig. 4. Flows of embedded greenhouse gas (GHG) emissions worldwide. Country codes are specified in Table 1.

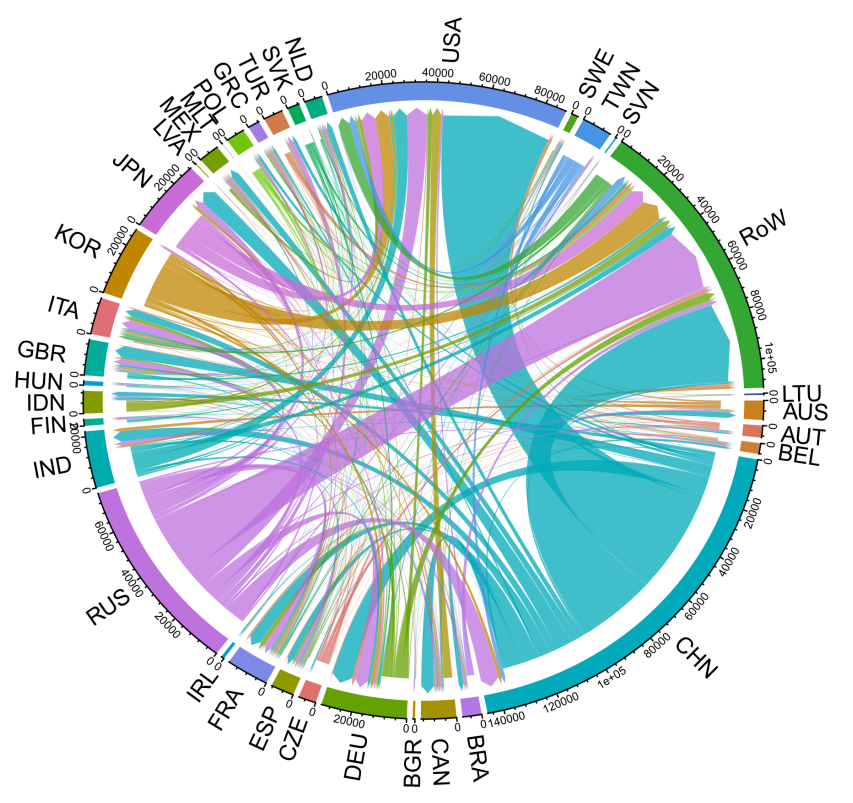

Germany also induces the largest volume of third party imports for final consumption and intermediate input (i.e., downstream spillovers; light red bars in Fig. 5). In other words, many other countries' consumption and further production of metals rely on the imports from Germany. Following Germany are Japan and China, the same as ranked in the list of gross exports. The USA, however, is ranked lower here than it was in the list of gross exports, indicating a relatively smaller proportion of the value of its exports is consumed in the third parties. The upstream spillovers of embedded GHG emissions (dark red bars in Fig. 6) show a similar pattern to those of VAX (dark red bars in Fig. 5). For the downstream spillovers of embedded GHG emissions (light red bars in Fig. 6), it is striking that China and Russia are far ahead of other countries.

\section{DISCUSSION}

Flows

Our results show that in 2009 over 200 million tons of carbon emissions were transferred through the trade of metals all over the world (Table 1), primarily from the developed countries to the developing countries (Fig. 3). There are two major flows of metals worldwide: those between East Asian countries to North America (mainly the USA, and also Canada and Mexico) and those between European countries, wherein Germany and Italy are major net exporters and the UK and France are major net importers (Fig. 3). The flows of embedded GHG emissions, however, generally originate in East Asian countries and Russia, whereas both America and Europe are net importers (Table 1). The USA is the largest net importer of products and the largest net receiver of embedded carbon emissions.

Fig. 5. Upstream and downstream spillovers of valued added exports (VAX) by country. Countries are sorted from top to bottom by upstream spillover. Country codes are specified in Table 1 .

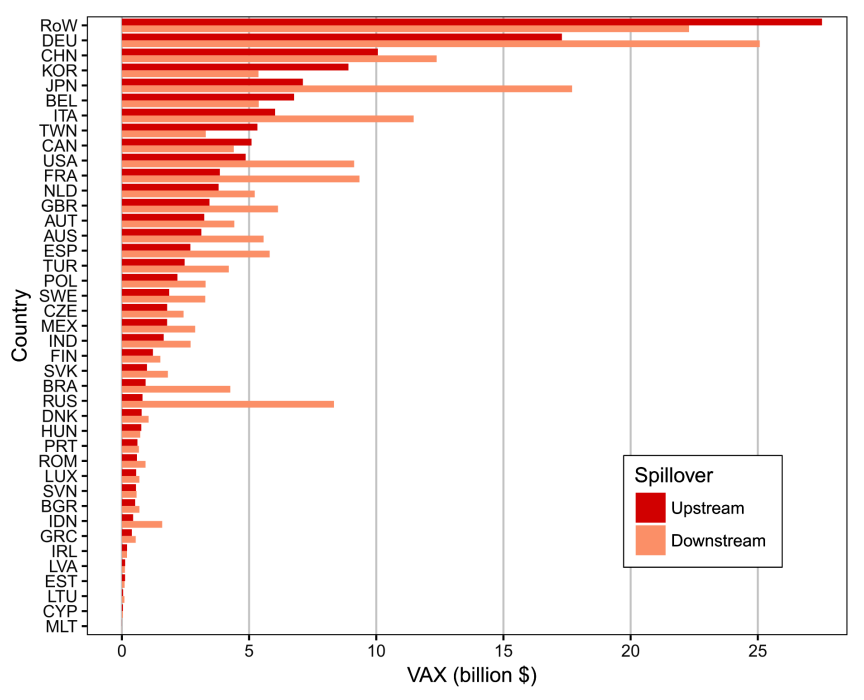

Fig. 6. Upstream and downstream spillovers of embedded greenhouse gas (GHG) emissions by country. Countries are sorted from top to bottom by upstream spillover. Country codes are specified in Table 1.

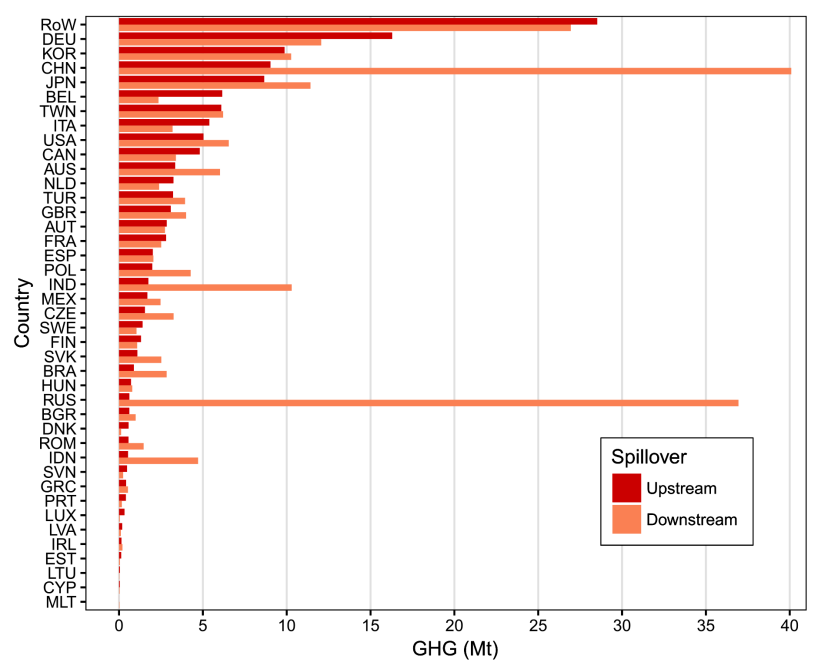


The imbalanced flows of emissions between developed countries and developing countries provides new evidence of ecologically unequal exchange (Rice 2007, Moran et al. 2013). A welldocumented reason for this is the pollution haven hypothesis. That is, developed countries externalize their pollution-intensive manufacturing to developing countries and retain the cleaner manufacturing processes at home (Hornborg and Jorgensen 2010, Prell et al. 2014). This transfer is economically motivated because developing countries often execute less stringent environmental regulations, and conversely, developed countries have stricter environmental regulations. It is therefore more expensive for companies to meet environmental standards in developed countries (Levinson and Taylor 2008, Millimet and Roy 2016). The environmental Kuznets curve hypothesizes a relationship between economic growth and environmental degradation that could contribute to the imbalanced emission flows. This hypothesis implies that degradation and pollution increase in the early stages of economic growth and the trend reverses when the economy reaches a certain level (Dinda 2004, Prell et al. 2014).

Analyzing differences in VAX compared to embedded GHG emissions allows insights about the types of industries that use metals within telecoupled trade. For example, China is a net importer from Japan for VAX but a net exporter to Japan of GHG (compare Fig. 3 and Fig. 4); that is, China holds deficits in both the economic and environmental accounts in the trade with Japan. This is a common phenomenon in the trade between countries with more and less developed economies (e.g., between Poland/ Hungary/Turkey and Germany/Italy, Russia and Japan/ Germany, and Brazil/India and Italy). A major contribution to this phenomenon is that the less developed economy is generally located more upstream in the value chain, and thus more specialized in producing carbon intensive but low value-added products in the global division of labor. For instance, China generally exports intermediate products that require more energy to produce and have lower prices (due to low value added) than Japan. Japan then uses its more advanced technologies to add value to the products with small energy use and then re-exports them to China at much higher prices. The disparity of emissions between the two countries is strengthened by the fact that the emission intensity of metal industries in the less developed economy is higher. This phenomenon is rooted in the institutional situation that more developed countries generally apply stricter environmental regulations, and it is an important contributor to carbon leakage worldwide (e.g., Babiker 2005).

\section{Spillovers}

Countries' different contributions to spillover effects can be better understood by considering their upstreamness in the GVC and not simply their total trade volumes. For example, we observe differences between USA, Italy, and Canada in terms of their relative ranking in total export of products compared to spillovers; despite the USA having larger total exports (Export in Table 1), the two smaller exporters have greater upstream spillovers of value added (Fig. 5). This is the case largely because the USA's upstreamness of metals (3.13) is greater than Italy's (2.89) and Canada's (2.97); in other words, Italy and Canada are located further downstream in the GVC and so the products they export generally rely more on intermediate inputs from upstream countries. We also notice that Belgium has a slightly higher upstreamness (3.21) than the USA, but still generates more upstream spillovers than the USA (Figs. 5, 6). This result is shaped by the fact that Belgium has an extremely high proportion of upstream spillovers to gross export (24\%, the third highest among all countries) compared to the USA $(0.08 \%$, the fourth lowest).

The dominance of China and Russia in downstream spillovers (Fig. 6) can be explained in part by their high GHG emission intensities (Table 1). Russia and China have GHG of 2.05 and 0.48 , respectively, which are large compared to Germany with 0.19 , USA with 0.21 , Japan with 0.21 , and South Korea with 0.32 . The major contribution to Russia's extremely high emissions intensity is the use of old production facilities and more energy intensive technologies overall. For instance, more than $20 \%$ of its production uses open an hearth furnace, a technology not used today in other large steel producers in the world (McKinsey and Company 2009). China's iron and steel industry is undergoing a low-carbon transition accompanied by remarkable technological progress, but its share of production using electric arc furnaces, which has lower $\mathrm{CO}_{2}$ emissions intensity than production using blast furnaces/basic oxygen furnaces, is still below $10 \%$, compared to $30 \%$ in Germany, $61 \%$ in the USA, $22 \%$ in Japan, and $42 \%$ in South Korea, in 2010 (BIR 2015, Hasanbeigi et al. 2016).

\section{Agents, causes, and effects}

Our quantitative analyses using the MRIO approach have focused on flows, but future studies should consider how other aspects of the telecoupling framework are represented in trade, including agents, causes, and effects (Liu et al. 2013). Agents in trade are the people or decision-making entities that facilitate or regulate the production, transaction, and consumption of the traded products. They specifically include producers and consumers, public or private investors, export and import agencies, and the financial investors. Governments are a final and important agent in international trade, making and enforcing trade agreements and policies influencing domestic production and consumption. In the case of metal products trade, the key agents are metal companies who frequently act as both producers and traders and can influence both the causes and effects of trade. Because of the dual role these companies can take, future studies that examine how their decision making shapes the pattern of metals trade might exploit the flexibility that agent-based approaches to modelling can offer (e.g., Farmer and Foley 2009).

Causes and effects are another key component in the telecoupling framework. International trade theories traditionally commit themselves to accounting for the economic causes of trade (both export and import) and the evaluation of its effects. These classical theories leave a large gap in accounting for environmental aspects of trade. However, as mentioned earlier, more recent trade theories (such as the pollution haven hypothesis and environmental Kuznets curve hypothesis) now provide consideration of the environmental causes and effects of trade. Complementarily use of these theories with environmental theories such the theory of ecological unequal exchange (Rice 2007), while also capitalizing on new global data sets, will help contribute to a more comprehensive understanding of the socioeconomic and environmental causes of world trade as viewed through the lens of the telecoupling framework.

\section{CONCLUSION}

The telecoupling framework offers a means to examine complex relationships between coupled human-natural systems over large 
distances to better understand the possibilities for global sustainability. Our aim was to contribute to improvements in the quantification of flows between different CHANS and particularly for spillover effects, using global trade as an example. The results of the application of our methods show how the impacts of trade can be understood in new ways when analyzing a MRIO dataset (i.e., WIOD) using the telecoupling framework. In particular, the use of the telecoupling framework has allowed us to investigate how countries contribute to both economic and environmental flows, but also how their contribution varies because of bilateral trade compared to spillover flows due to their position in the GVC. We thus gain an extensive view of both economic versus environmental impacts and direct versus indirect impacts that a country generates and receives. By making comparisons between countries' contributions to different flows (e.g. Figs. 5, 6), we are able to understand contributions beyond the volumes of trade (Table 1) and bilateral trade (Figs. 3 and 4). Specifically, we have interpreted the differences between countries' contributions to the flows of products versus embedded GHG emissions as being related to their emission intensities. In turn, differences in contributions to direct flows versus spillover flows is related to their positions in the GVC (i.e., upstreamness). Our analysis used the World Input-Output Database, which provides useful worldwide dataset for the examination of spillovers, but only at a broad sectoral level and for national economies. Continued improvements in data sources will be needed to build on initial quantification like ours to establish environmental effects and impacts of spillovers at finer industrial aggregations and at subnational levels. More comprehensive use of the telecoupling framework would incorporate representation of decision making to understand influences of agents on trade flows and spillovers, and this will require yet further innovation in data and models.

Responses to this article can be read online at: http://www.ecologyandsociety.org/issues/responses. $\mathrm{php} / 9864$

\section{Acknowledgments:}

This work was supported by the Natural Environment Research Council [grant number NE/M021335/1], the National Natural Science Foundation of China [grant number 41671037], and the National Key Research and Development Program of China [grant number 2016 YFA0602402].

\section{LITERATURE CITED}

Antràs, P., and D. Chor. 2013. Organizing the global value chain. Econometrica 81(6):2127-2204. http://dx.doi.org/10.3386/w18163

Antràs, P., D. Chor, T. Fally, and R. Hillberry. 2012. Measuring the upstreamness of production and trade flows. American Economic Review 102(3):412-416. http://dx.doi.org/10.1257/ aer.102.3.412

Babiker, M. H. 2005. Climate change policy, market structure, and carbon leakage. Journal of International Economics 65 (2):421-445. http://dx.doi.org/10.1016/j.jinteco.2004.01.003
Baldwin, R., and J. Lopez-Gonzalez. 2015. Supply-chain trade: a portrait of global patterns and several testable hypotheses. World Economy 38(11):1682-1721. http://dx.doi.org/10.1111/ twec.12189

Bureau of International Recycling (BIR). 2015. World steel recycling in figures 2010-2014. Bureau of International Recycling, Ferrous Division, Brussels, Belgium. [online] URL: http://www. eawag.ch/fileadmin/Domain1/Abteilungen/sandec/E-Learning/Moocs/ Solid Waste/W1/World steel recycling 2015.pdf

Cropper, M. L., and W. E. Oates. 1992. Environmental economics: a survey. Journal of Economic Literature 30(2):675-740.

Davis, S. J., and K. Caldeira. 2010. Consumption-based accounting of $\mathrm{CO} 2$ emissions. Proceedings of the National Academy of Sciences 107(12):5687-5692. http://dx.doi.org/10.1073/ pnas.0906974107

Davis, S. J., G. P. Peters, and K. Caldeira. 2011. The supply chain of $\mathrm{CO} 2$ emissions. Proceedings of the National Academy of Sciences 108(45):18554-18559. http://dx.doi.org/10.1073/pnas.1107409108

Diehl, M. 2001. International trade in intermediate inputs: the case of the automobile industry. Kiel Working Paper, No. 1027. Kiel Institute for the World Economy, Kiel, Germany. [online] URL: https://www.econstor.eu/bitstream/10419/17738/1/kap1027.pdf

Dinda, S. 2004. Environmental Kuznets curve hypothesis: a survey. Ecological Economics 49(4):431-455. http://dx.doi. org/10.1016/j.ecolecon.2004.02.011

Farmer, J. D., and D. Foley. 2009. The economy needs agent-based modelling. Nature 460(7256):685-686. http://dx.doi.org/10.1038/460685a

Fearnside, P. M., A. M. R. Figueiredo, and S. C. M. Bonjour. 2013. Amazonian forest loss and the long reach of China's influence. Environment, Development and Sustainability 15 (2):325-338. http://dx.doi.org/10.1007/s10668-012-9412-2

Frankel, J. 2009. Environmental effects of international trade. Globalisation Council, Oslo, Sweden. [online] URL: https://sites. hks.harvard.edu/fs/jfrankel/Swenvirinlaga31proofs.pdf

Gibbon, P., J. Bair, and S. Ponte. 2008. Governing global value chains: an introduction. Economy and Society 37(3):315-338. http://dx.doi.org/10.1080/03085140802172656

Grossman, G. M., and A. B. Krueger. 1991. Environmental impacts of a North American Free Trade Agreement. National Bureau of Economic Research Working Paper Series No. 3914 (3914):1-57. http://dx.doi.org/10.3386/w3914

Hasanbeigi, A., M. Arens, J. C. R. Cardenas, L. Price, and R. Triolo. 2016. Comparison of carbon dioxide emissions intensity of steel production in China, Germany, Mexico, and the United States. Resources, Conservation and Recycling 113:127-139. http:// dx.doi.org/10.1016/j.resconrec.2016.06.008

Hertwich, E. G., and G. P. Peters. 2009. Carbon footprint of nations: a global, trade-linked analysis. Environmental Science and Technology 43(16):6414-6420. http://dx.doi.org/10.1021/ es803496a

Hornborg, A., and A. K. Jorgensen. 2010. International trade and environmental justice: toward a global political ecology. Nova Science, Hauppauge, New York, New York, USA. 
Johnson, R. C., and G. Noguera. 2012. Accounting for intermediates: production sharing and trade in value added. Journal of International Economics 86(2):224-236. http://dx.doi. org/10.1016/j.jinteco.2011.10.003

Karp, L. 2011. The environment and trade. Annual Review of Resource Economics 3(1):397-417. http://dx.doi.org/10.1146/ annurev-resource-083110-115949

Levinson, A., and M. S. Taylor. 2008. Unmasking the pollution haven effect. International Economic Review 49(1):223-254. http:// dx.doi.org/10.1111/j.1468-2354.2008.00478.x

Li, H., Z. Pei Dong, H. Chunyu, and G. Wang. 2007. Evaluating the effects of embodied energy in international trade on ecological footprint in China. Ecological Economics 62(1):136-148. http:// dx.doi.org/10.1016/j.ecolecon.2006.06.007

Liu, J., V. Hull, M. Batistella, R. DeFries, T. Dietz, F. Fu, T. W. Hertel, R. C. Izaurralde, E. F. Lambin, S. Li, L. A. Martinelli, W. J. McConnell, E. F. Moran, R. Naylor, Z. Ouyang, K. R. Polenske, A. Reenberg, G. de Miranda Rocha, C. S. Simmons, P. H. Verburg, P. M. Vitousek, F. Zhang, and C. Zhu. 2013. Framing sustainability in a telecoupled world. Ecology and Society 18 (2):26. http://dx.doi.org/10.5751/ES-05873-180226

Liu, J., H. Mooney, V. Hull, S. J. Davis, J. Gaskell, T. Hertel, J. Lubchenco, K. C. Seto, P. Gleick, C. Kremen, and S. Li. 2015. Systems integration for global sustainability. Science 347 (6225):1258832. http://dx.doi.org/10.1126/science.1258832

Mani, M., and D. Wheeler. 1998. In search of pollution havens? Dirty industry in the world economy, 1960 to 1995. Journal of Environment and Development 7(3):215-247. http://dx.doi. org/10.1177/107049659800700302

McKinsey and Company. 2009. Pathway to an energy and carbon efficient Russia: opportunities to increase energy efficiency and reduce greenhouse gas emissions. McKinsey and Company, Moscow, Russia. [online] URL: https://www.mckinsey.com/ business-functions/sustainability-and-resource-productivity/ourinsights/pathways-to-an-energy-and-carbon-efficient-russia

Meng, B., G. P. Peters, and Z. Wang. 2015. Tracing greenhouse gas emissions in global value chains. Stanford Center on Global Poverty and Development, Stanford, California, USA. [online] URL: https://globalpoverty.stanford.edu/sites/default/files/ publications/525wp 0.pdf

Millimet, D. L., and J. Roy. 2016. Empirical tests of the pollution haven hypothesis when environmental regulation is endogenous. Journal of Applied Econometrics 31(4):652-677. http://dx.doi. org/10.1002/jae.2451

Moran, D. D., M. Lenzen, K. Kanemoto, and A. Geschke. 2013. Does ecologically unequal exchange occur? Ecological Economics 89:177-186. http://dx.doi.org/10.1016/j.ecolecon.2013.02.013

Norder, S. J., A. C. Seijmonsbergen, S. D. D. V. Rughooputh, E. E. van Loon, V. Tatayah, A. T. Kamminga, and K. F. Rijsdijk. 2017. Assessing temporal couplings in social-ecological island systems: historical deforestation and soil loss on Mauritius (Indian Ocean). Ecology and Society 22(1):29. http://dx.doi. org/10.5751/ES-09073-220129
Peters, G. P. 2008. From production-based to consumption-based national emission inventories. Ecological Economics 65(1):13-23. http://dx.doi.org/10.1016/j.ecolecon.2007.10.014

Peters, G. P., and E. G. Hertwich. 2008. Post-Kyoto greenhouse gas inventories: production versus consumption. Climatic Change 86(1-2):51-66. http://dx.doi.org/10.1007/s10584-007-9280-1

Peters, G. P., J. C. Minx, C. L. Weber, and O. Edenhofer. 2011. Growth in emission transfers via international trade from 1990 to 2008. Proceedings of the National Academy of Sciences 108 (1):8903-8908. http://dx.doi.org/10.1073/pnas.1006388108

Prell, C., and K. Feng. 2016. The evolution of global trade and impacts on countries' carbon trade imbalances. Social Networks 46:87-100. http://dx.doi.org/10.1016/j.socnet.2016.03.001

Prell, C., K. Feng, L. Sun, M. Geores, and K. Hubacek. 2014. The economic gains and environmental losses of US consumption: a world-systems and input-output approach. Social Forces 93(1):405-428. http://dx.doi.org/10.1093/sf/sou048

Prell, C., and L. Sun. 2015. Unequal carbon exchanges: understanding pollution embodied in global trade. Environmental Sociology 1(4):256-267. http://dx.doi.org/10.1080/23251042.2015.1114208

Prell, C., L. Sun, K. Feng, J. He, and K. Hubacek. 2017. Uncovering the spatially distant feedback loops of global trade: a network and input-output approach. Science of the Total Environment 586:401-408. http://dx.doi.org/10.1016/j. scitotenv.2016.11.202

Rice, J. 2007. Ecological unequal exchange: consumption, equity, and unsustainable structural relationships within the global economy. International Journal of Comparative Sociology 48 (1):43-72. http://dx.doi.org/10.1177/0020715207072159

Shafik, N., and S. Bandyopadhyay. 1992. Economic growth and environmental quality: time series and cross-country evidence. World Bank, Washington, D.C., USA. [online] URL: http:// documents.worldbank.org/curated/en/833431468739515725/pdf/ multi-page.pdf

Steinberger, J. K., J. T. Roberts, G. P. Peters, and G. Baiocchi. 2012. Pathways of human development and carbon emissions embodied in trade. Nature Climate Change 2(2):81-85. http://dx. doi.org/10.1038/nclimate1371

Timmer, M. P., E. Dietzenbacher, B. Los, R. Stehrer, and G. J. de Vries. 2015. An illustrated user guide to the world input-output database: the case of global automotive production. Review of International Economics 23(3):575-605. http://dx.doi.org/10.1111/ roie. 12178

Tobey, J. A. 1990. The effects of domestic environmental policies on patterns of world trade: an empirical test. Kyklos 43 (2):191-209. http://dx.doi.org/10.1111/j.1467-6435.1990.tb00207. $\underline{x}$

United Nations. 2014. System of environmental-economic accounting 2012 - central framework. United Nations, New York, New York, USA. [online] URL: https://unstats.un.org/unsd/ envaccounting/seearev/seea cf final en.pdf

Wang, Z., S.-J. Wei, and K. Zhu. 2013. Quantifying international production sharing at the bilateral and sector levels. NBER Woking Papers 19667:1-127. http://dx.doi.org/10.3386/w19677 
Weber, C. L., and H. S. Matthews. 2007. Embodied environmental emissions in U.S. international trade, 1997-2004. Environmental Science and Technology 41(14):4875-4881.

Wiebe, K. S., and N. Yamano. 2016. Estimating CO2 emissions embodied in final demand and trade using the OECD ICIO 2015: methodology and results. OECD Science, Technology and Industry Working Papers No. 2016/05. OECD Publishing, Paris, France. [online] URL: http://www.oecd-ilibrary.org/docserver/ download $/ 5 \mathrm{jl} \mathrm{rcm} 216 \mathrm{xkl}$-en.pdf?expires $=1515643715 \& \mathrm{id}=\mathrm{id} \&$ accname $=$ guest\&checksum =974C1C7B59B1FC7F0929CC0BAD5AEDA3 
Appendix 1. Decomposition of gross exports and identification of components composing upstream and downstream spillovers

The following figure presents how gross export can be completely decomposed into 16 nonoverlapping components.

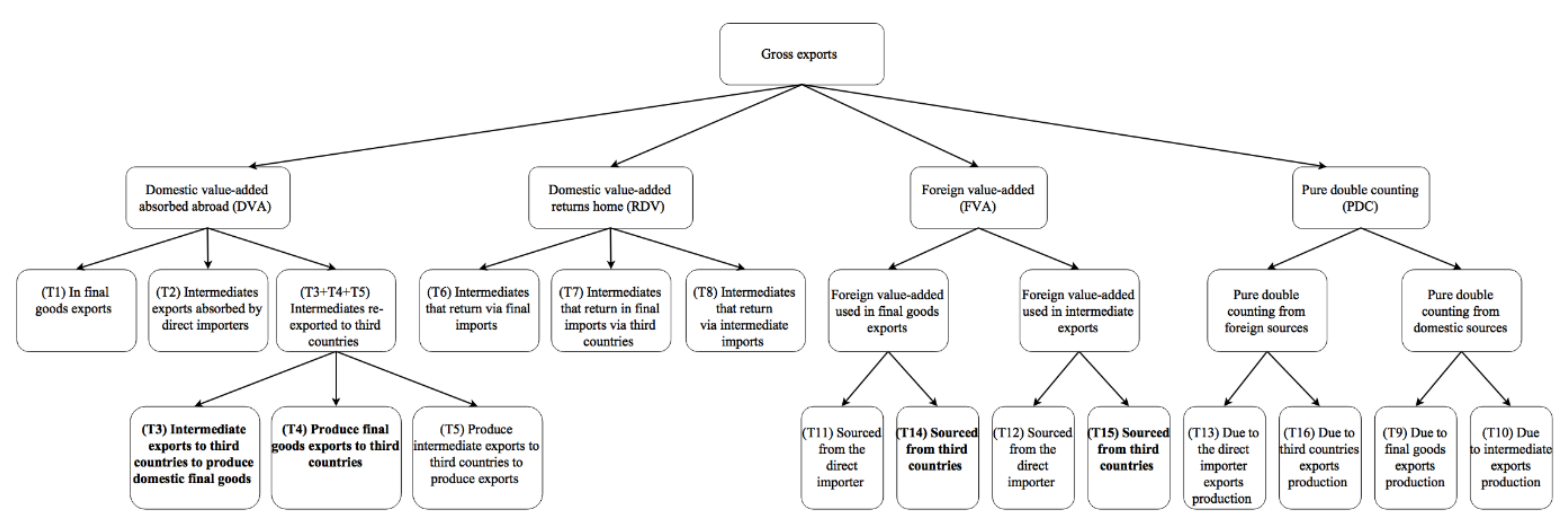

Fig. A1.1. Decomposition of gross exports. Gross exports are entirely decomposed into 16 non-overlapping components (T1 to T16). Quoted from Wang et al. (2013).

Among these 16 components, the value added sourced from third parties is divided into that used as final products (T14 as labelled in the original paper) and intermediate products (T15). Together these represent third party production induced by exports, and thus the sum of T14 and T15 gives a measure of upstream spillovers. Likewise, the value added transported to third parties as intermediate products (T3) and final products (T4) represent the consumption induced by exports. The sum of T3 and T4 thus gives a measure of downstream spillovers.

The four components (T3, T4, T14 and T15) as well as upstream and downstream spillovers can be illustrated using the example of auto parts and automobile trade in the main text. Suppose that China further imports intermediate products from Russia and the USA further exports final products to Canada. In this case the four components can be depicted as shown in Fig. 2 in the main text, where Poland's export to Germany is taken as the focal export to be decomposed. In this example of telecoupled trade, Poland is the sending system and Germany is the receiving system, and the remaining four countries are third parties. On the production side, China's contribution of providing final products to the production of the traded products is T14, and Russia's contribution of providing intermediate products is T15. The sum of T14 and T15 is the upstream spillover of the Poland-Germany trade. In the consumption, USA's consumption of the traded products as final products is T4, and Canada's consumption as intermediate products are T3. The sum of T4 and T3 is the downstream spillovers of the trade. 
Appendix 2. Steps analysing the WIOD data

A summary of the steps analysing the WIOD data are presented in Fig. A2.1. On one hand, we used the original method presented in Johnson and Noguera (2012) to calculate the net flows of value added (i.e. the flows of VAX) from exporting to importing countries with socio-economic accounts of the WIOD, and then modified this method to calculate the net flows of embedded GHG emissions with environmental accounts. The results are shown in Fig. 5 and 6, respectively. On the other hand, we used the original method presented in Wang et al. (2013) to calculate the net flows of value added from exporting to third countries (i.e. downstream spillovers) and from third to exporting countries (i.e. upstream spillovers) with socio-economic account, and then modified this method to calculate corresponding net flows of embedded GHG emissions with environmental accounts. The results are shown in Fig. 7 and 8, respectively. Analyses were performed in R 3.2.2, utilising the 'decompr' package (Quast et al. 2016) for flow decompositions and the 'circlize' package (Gu et al. 2014) for flow diagrams.
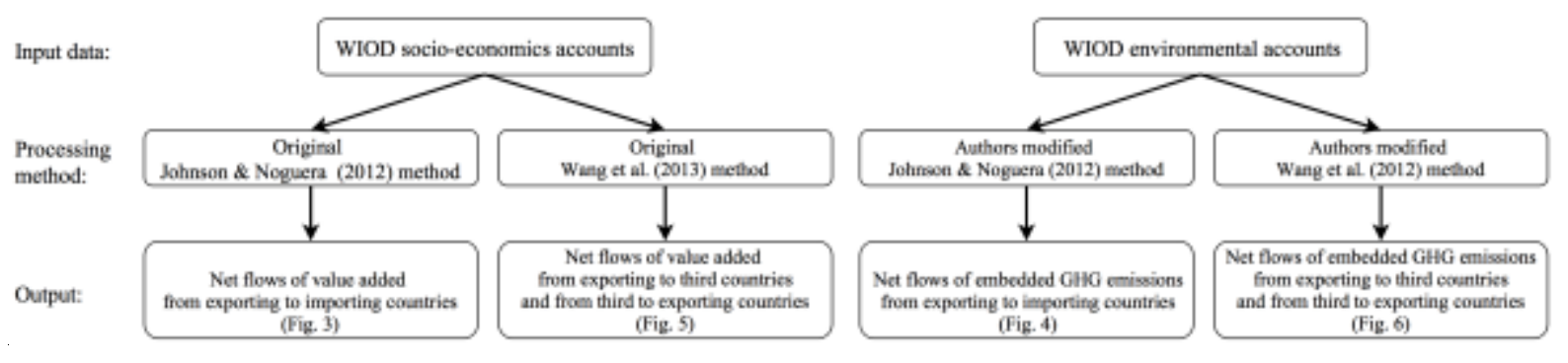

Fig. A2.1. Steps analysing the WIOD data 